\title{
Enabling Community-Owned Platforms: A Proposal for a Tech New Deal
}

\author{
Nathan Schneider \\ University of Colorado Boulder
}

PREPRINT

In Regulating Big Tech: Policy Responses to Digital Dominance, ed. Martin Moore and Damian Tambini (Oxford University Press, 2021)

At a time when regulators are seeking new responses to the dilemmas of world-spanning digital platforms, forms of community ownership such as cooperatives and trusts offer attractive benefits for workers and other users. Yet if economic democracy is to provide a counterweight to investor ownership in the online economy, it will require an appropriate policy framework. This paper argues that such a framework can come from radically generalizing and expanding on pre-digital successes in local and industry-specific policies from various countries and contexts - including policies for incorporation, financing, and coordination. Policy should use community ownership not just to solve specific problems but as a universal means of organizing innovation. It should also seek to repair past injustices to communities marginalized through under-investment. Community ownership could thereby become at least as available to the online economy as investor ownership has been.

keywords: digital economy, cooperatives, economic democracy, employee ownership, finance, Internet regulation, platform cooperativism

The author is grateful for substantive feedback on drafts from Fred Freundlich, Pete Davis, Martin Moore, Doug O'Brien, and Jonas Pentzien. Work on this essay was supported in part by a fellowship with the Open Society Foundations. The opinions expressed herein are the author's own and do not necessarily express the views of the Open Society Foundations. 
Economic crises highlight not just preexisting failures of distribution - the bread lines, the shantytowns - but also failures of production: the blindness among allocators of capital to vast terrains of opportunity and human potential. Times of crisis have therefore compelled governments not just to mobilize redistributive measures but also to adopt more sensible forms of productive allocation, forms that usually had long seemed necessary at the margins but were ignored at the center until the center itself began to buckle.

The crisis brought on by the COVID-19 pandemic, for one, has surfaced many such failures - although for people experiencing them directly they come as no surprise. The platform-guided gig workers making deliveries and caring for elders have become "essential workers," a designation that stands in stark contrast to the platforms' refusal to afford them employee status or basic protections. Public health orders to work from home don't compute in rural and urban communities where telecom companies have long refused to deploy modern connectivity. The regime of "social distancing" further deepens the reliance of many on apps that treat surveillance as the price of connecting with friends, family, and coworkers - offering few guarantees about what might or might not be done someday with all the data.

At a time when regulators are seeking new responses to the dilemmas of world-spanning digital platforms, cooperative ownership has been a matter of growing discussion and experimentation (Scholz and Schneider 2016; Schneider 2018b). A cooperative of gig-economy workers could distribute profits more equitably than has been the case, as investor-owned platforms have tended toward a race to the bottom in terms of wages and working conditions (Scholz 2017; Schor 2020). A social-media cooperative could give users the power to oversee how their personal data can be monetized and prevent abuses (Pasquale 2015; Zuboff 2019). Through cooperative federations, platforms could reduce their antitrust exposure by balancing local control with global network effects (Vaheesan and Schneider 2019). In turn, rather than relying solely on external regulation within territorial jurisdictions, platforms could be subject to internal regulation from their user communities. Aligning business and participant interests through coownership could meanwhile introduce new efficiencies (Albæk and Schultz 1998; Bogetoft 2005; Mikami 2011; Molk 2014; Blasi, Kruse, and Freeman 2018). Policymakers in several countries have expressed formal or informal interest in the idea, including the British Labour Party (Corbyn 2016), the German Social Democratic Party (Scholz 2018a), the Innovation Committee of the Italian Parliament in Rome (Sifry 2016), the city of Barcelona (Morell and Espelt 2018; Bria 2019), and US senator Kirsten Gillibrand (Scholz 
2018b).

The market share of actually existing platform cooperatives remains close to negligible (Schneider 2018a, 155-62). They have rarely been able to access external financing, and thus they lack the infrastructure of advisors, incubators, and accelerators that are typically tied to such financing (Lloyd, Symons, and Borkin 2019). Even when tech giants such as Airbnb and Uber have sought to practice equity compensation with their user-workers, they have encountered regulatory barriers (Robbins, Schlaefer, and Lutrin 2018). For all the near-magical properties ascribed to the platform economynotably, rampant disintermediation and negligible marginal costs (Rifkin 2014; Parker, Alstyne, and Choudary 2016) - why have platforms not transcended the conventional corporation into a utopia of co-ownership?

The answer lies in the recognition that what can and cannot be done in private enterprise depends on public policies that lurk in the background, often unnoticed and uncredited. Silicon Valley-style venture capital, for instance - however much its doyens might like to declare independence from the ancien régime of offline government (Barlow 1996) — owes a considerable portion of its success to the US Congress's 1979 amendment to the "prudent man" rule, opening the door to investment from pension funds (Nicholas 2019, 176).

Success in most arenas of community-owned business has also relied on dedicated policy. To consider US history again, the Great Depression-era New Deal legislation included mechanisms for financing cooperatives in the Farm Credit Act (1933), the Federal Credit Union Act (1934), and the Rural Electrification Act (1936); programs around retirement and homeownership further encouraged widespread capital ownership. Where community ownership has flourished internationally, it has come with similar litanies of such provisions (Mayo 2017; Pentzien 2020). It thus stands to reason that economic democracy for the online economy will require an appropriate policy framework, an outline of which I offer here.

The solution, however, is not simply to carve out the Internet as yet another special case in which a distinct and bounded cooperative sector might emerge. Investor-owned businesses, across wildly diverse sectors, operate under general-purpose methods of incorporation and financing; community ownership could do the same. It could be a means of discovering latent value in our networks, data, and work, which the investor-oriented models are not able to notice. 
I will draw on successful cooperative policies in various countries and industries, and propose ways of generalizing them broadly across the economyincluding to the online economy. The New Deal era was an especially generative time in the United States for visionary, targeted policies for democratizing ownership, from housing to financial institutions. These, in turn, took inspiration from earlier, small-scale experiments (Knapp 1973; Curl 2012). The "Tech New Deal" I propose here draws on the New Deal and related policy legacies as test runs for a more ambitious agenda, one capable of undergirding economic democracy for a time of global networks that are at once embattled in controversy and pregnant with possibility. But as a generalized framework, the Tech New Deal should be considered of a piece with related undertakings, such as calls for a Green New Deal or large-scale economic recovery programs. Policy should use community ownership not just to solve specific problems but as a universal means of organizing innovation. It should also seek to repair past injustices to communities marginalized through under-investment. This agenda sets out to ensure that community ownership is at least as available to the online economy as investor ownership has been.

I employ the spacious frame of "community ownership" to include a variety of relevant legal mechanisms, such as cooperatives, stock-owning trusts, and democratic nonprofits. Community members might be workers, users, or businesses, depending on who happen to be the central stakeholders in a given context. Yet community ownership should be "broad-based" among all or most members of any stakeholder class (Blasi, Kruse, and Freeman 2018), rather than including only an elite subset of stakeholders. The imprecision of community reflects the respects in which online platforms have unsettled familiar notions of stakeholdership in economic life. In each case, however, a given firm would define its community of stakeholders precisely to ensure clear lines of ownership and governance. Appropriate community stakeholders might include those most responsible for the firm's behavior (e.g., employees and other workers) and those who contribute value to it (e.g., users contributing original content and personal data).

In what follows, I begin by reviewing the constraints that community ownership faces under present conditions, which limit its capacity to compete fairly with investor ownership. I will then introduce three "vectors of democratization," drawing on earlier legacies to propose an agenda for radically emboldening community ownership in an age of global networks. Finally, I conclude by considering the political strategies that might advance such an agenda. 


\section{Constraints on and for community ownership}

The startups that have come to dominate the online economy have a peculiar relationship with regulation. In the spirit of John Perry Barlow (1996)'s "Declaration of the Independence of Cyberspace," tech startups established markets seemingly immune to the rules imposed on foregoing businesses through gray-area operations and regulatory arbitrage. Ridesharing apps in many jurisdictions operate outside of taxi regulations; communications platforms help themselves to kinds of user surveillance unavailable to earlier phone companies and parcel services; social networks can distribute news items without bearing the news producers' liability for the content. It is as if Barlow's Silicon Valley friends made good on his warning to the governments of the world: "You have no moral right to rule us nor do you possess any methods of enforcement we have true reason to fear." Meanwhile, the old rules keep on inhibiting the startups' incumbent competitors.

To pay for the risks of such gray-area, winner-takes-all business models, Internet startups typically rely on venture capital financing - a kind of Faustian bargain that pays for risk tolerance with a demand for growth at all costs and the prospect of lavish rewards for early bets. This arrangement has produced a critical mass of the world's most valuable companies, though it has also earned critics among startup founders for failing to serve diverse aspirations and leaders (Griffith 2019). Venture capital has thus far been ill-equipped to invest in community-owned enterprises, which tend to avoid the risks of regulatory arbitrage and refuse the degrees of investor power that venture capital needs in order to compensate for failed investments. The lower risk profile found in community ownership (Molk 2014; Blasi, Kruse, and Freeman 2018), however, could be attractive in economies outside the relatively rare urban tech hubs where venture capital concentrates and flourishes (Florida 2017). But thus far cooperative and other community-owned Internet startups have struggled to access necessary capital. While they reject the growth-at-all-costs logic that venture demands, they still present risks that legacy cooperative banks, credit unions, and public financing were not built to tolerate.

Policies to promote community ownership have often included provisions for "technical assistance" grants to support startups in business processes (Kerr 2015). Yet support tends to become scalable and sustainable only when there a viable means of capital access that businesses can aspire toward. When investment opportunities are present, entities such as accelerators and incubators arise around them. Without proper investment infrastructure, 
the infrastructure for entrepreneur education and mentoring will not persist long after the grant periods end.

In addition to what policy does and doesn't enable, policy has the power to restrict. Certain well-placed inhibitors of rampant platform capitalism are needed, and there has been no lack of discussion on what those should be. For example, robust privacy regulations could threaten the dominance of surveillance-based platforms and benefit competitors that prioritize users' ownership and control over their data. Labor enforcement could undermine the current gig-economy business model and spur the development of platforms premised on more secure employment. Without restrictions on exploitative practices, higher-road alternatives will have a hard time competing.

For better or worse, the most effective resistance to Silicon Valley giants has come through protectionist regulatory enforcement. The case of China stands out; its "Great Firewall" has served the dual purpose of aiding in political censorship and keeping out certain US platforms so that local alternatives could gain market share and flourish (Chu 2017). There are less drastic examples as well. Austin, Texas, for instance, saw the rise of a nonprofit ride-sharing platform after officials drove Uber and Lyft out of the city by requiring the companies to abide by safety regulations required of taxis (Davidson 2017). Other cities, from London (Spicer 2019) to Seoul (Moon 2017), have similarly barred platforms from operating above the law - while facilitating the development of their own platforms in the process.

As with any other sort of alternative to dominant platforms, communityowned platforms are unlikely to gain a foothold unless there are barriers in place to constrain better-capitalized competitors that lack community accountability. But along with such constraints must come strategies that enable healthier, more democratic ownership to take hold.

\section{Vectors of democratization}

This section presents vectors for advancing community ownership for the online economy and beyond. I refer to them as vectors to emphasize that, in each case, these policies for the future share lines of continuity with narrower but well-tested policies of the past and present. They set out to universalize access to community ownership for the networked age in three directions:

- Versatile statutes for firm incorporation and membership

- Access to scalable financing for diverse communities 
- Enablers of coordination and collective voice

\section{Incorporation: from localities to networks}

According to George Jacob Holyoake, an early chronicler of the British cooperative movement, the 1846 Friendly Societies Act presented working people with "an advantage so great that the most sanguine despaired of living to see its enactment" (Holyoake 1908, 290). Just two years after the birth of the Rochdale cooperative store, a foundational success story, Parliament enabled this nascent kind of business to incorporate with limited liability. Within a few years, similar stores were appearing throughout England, which joined forces through federations to manage joint factories, warehouses, and supply chains. From the 1840s to today's Delaware C Corporation-a favorite for Internet startups thousands of miles away in Silicon Valley-people's organizational imaginations live within the boxes of what policy regimes happen to enable.

Statutes for cooperative incorporation vary worldwide (Cracogna, Fici, and Henry 2013). Within the United States alone, the state of Mississippi does not allow for even basic worker-owned or consumer-owned cooperatives, while Colorado's Limited Cooperative Association statute can handle complex, multi-stakeholder structures with arbitrary member types, including a role for investor members. (Colorado lawyers Wiener and Phillips (2018) have called their state "the Delaware of cooperative law.") By and large, statutes for cooperatives and other forms of community ownership were designed for local or regional organizations with relatively stable memberships, not transnational networks whose users come and go with ease. So long as such statutes remain limited in scale and scope, community-ownership efforts will remain at a disadvantage compared to the tools available for investor-owned companies.

Corporate law need not be custom-made for online platforms. Colorado's Limited Cooperative Association is a "uniform law" enacted in several other states, originally for the purpose of rural development (Uniform Law Commission 2013); the law itself, however, does not limit its provisions to rural cooperatives, making it serviceable for many other applications, and it has been popular with platform startups. German cooperatives of any type similarly incorporate under a common statute (Pentzien 2020). A proposed Cooperative Platform Economy Act in California (Upside Down Consulting n.d.) would establish a new type of cooperative to handle employment for gig-economy platforms, but it could also address longstanding abuses in 
older, offline gig economies. The European Union, meanwhile, established in 2003 the Statute for a European Cooperative Society, which provides for cooperatives among citizens of more than one EU member state, facilitating cross-border collaboration - again, a boon for platforms whose constituencies are not nationally bounded. When such inter-governmental agreements are not forthcoming, there should be provisions for virtual membership, in which a platform's international users might hold de facto profit-sharing and governance powers, even if short of de jure company ownership.

Community ownership need not require distinctive company structures. The US Employee Stock Ownership Plan (ESOP), which achieved federal recognition and favorable tax treatment beginning in 1974, employs a trust that can hold shares in several different types of companies on employees' behalf; similar structures could be employed to hold platform assets for other kinds of communities (Schneider 2020b). Perpetual purpose trusts, although originally created for estate planning (Antoine 2013), are beginning to prove useful in conjoining community ownership with organizational mission (Michael 2017; Peters 2018), although this approach is little-tested and may not yet be sufficiently enforceable. Trust-mediated ownership could also provide the benefits of co-ownership for platform users who do not want a formal, ongoing stock-holding relationship with the company. Whether through direct or mediated means, community ownership should ensure that members can speak with a collective voice and counteract exploitation by managers and investors.

Recommendations in brief:

- Enable the incorporation of flexible legal mechanisms for community ownership

- Mechanisms should support international membership and multiple member classes

- Ensure purpose trusts are available and legally enforceable

\section{Financing: From sectoral to universal}

Community-owned enterprises face consistent and even crippling disadvantages in accessing capital. Compared to firms designed for investor ownership, community ownership by definition restricts the rights of outside capital providers. This goes a long way toward explaining, for instance, what Molk (2014) refers to as "the puzzling lack of cooperatives." When cooperatives have arisen historically, it has been due either to communities' ability to 
mobilize collective action and fill "missing markets" (Hueth 2014) or to tailormade policies that carved out exceptions to the general bias for investor ownership. Smaller cooperatives have often relied on member investment to start and grow; they could be considered the original crowdfunding, long before the likes of Kickstarter. But capital-intensive businesses - whether they are laying power lines or coding tech platforms - can't easily be built this way. There is promise in recent developments around "equity crowdfunding" through the USA JOBS Act (Catalini, Fazio, and Murray 2016), the UK's Community Shares model (Community Shares 2016), and blockchain-based token offerings (Rohr and Wright 2017), but none of these appears poised to supplant the need for institutional finance.

In the United States, policy interventions have been essential (and effective) in bringing community ownership to scale, such as through the Farm Credit System (Knapp 1969), credit unions (Taylor and Goodman 2019), rural electric cooperatives (Doyle 1979; Spinak 2014), and widespread employee ownership (Speiser 1977; Kroncke 2018). Each of these interventions involved either direct government financing or indirect inducements for private capital markets, such as insurance guarantees and tax incentives. Yet each case serves only very particular kinds of markets. As part of the Farm Credit System, the country's largest cooperative bank - CoBank - can only invest in rural cooperatives; credit unions are typically restricted to a certain "field of membership"; tax benefits for employee ownership occur only within the context of a particular type of retirement program. As with incorporation statutes, financing provisions for cooperatives around the world tend to revolve around certain sectors and lines of business, particularly in farming and small-scale finance (Cracogna, Fici, and Henrÿ 2013).

There have been understandable reasons for keeping policy interventions narrow. Doing so reduces risks for the public purse by targeting tested, replicable business models and judging investments according to uniform standards. Limiting interventions to specific, low-margin sectors also mitigates the political threat from the investor class, which could perceive (and often has) policy accommodations for community ownership as unfair competition; in the wake of the 1936 Rural Electrification Act, for instance, investor-owned electric companies built "spite lines"-power lines intended to divide and sabotage prospective cooperatives (Doyle 1979). Such reasons, however, need not forever constrain the potential of community ownership to isolated cases.

Examples of past successes in financing community ownership can inform 
an array of generalized policies capable of putting cooperatives and their ilk on par with investor ownership throughout the economy, including in the realm of online platforms. In order to do so, it will be necessary to update earlier risk-mitigation strategies - generally, the replication of tested, local models - in order to protect public investments. This might be done, for instance, through more strenuous diversification or the use of revenue-based financing to recoup greater returns from successful efforts.

Louis Kelso, inventor of the aforementioned ESOP, proposed an intriguing strategy for making community ownership more widely available: a government agency called the Capital Diffusion Reinsurance Corporation (Kelso and Kelso 1986; Schneider 2020a). Akin to public insurance for credit unions and agricultural cooperatives, this entity would vet and underwrite community-ownership financing or conversions in order to encourage investment. It would especially encourage lending to groups of under-capitalized people, while enabling access to capital ownership in the enterprises that they participate in as workers, customers, neighbors, and more. In this way, community financing could be part of a broader package of reparations for past historical injustices, such as the New Deal's under-investment in US communities of color.

Whether through insurance pools, direct lending, or tax inducements, the critical challenge of community-ownership finance is to counteract the conventional expectation of personal guarantees to secure capital, which favors small numbers of wealthy people. Collective ownership needs mechanisms to enable collective guarantees.

A further theme in Kelso and Kelso (1986)'s proposals is using public investment to enable community-owned, revenue-producing infrastructure. Such practices are in some respects common, ranging from the aforementioned electric cooperatives to indigenous tribal corporations, the sovereign wealth funds that many countries maintain, and the Alaska Permanent Fund, which distributes cash dividends to residents. Likewise, community ownership could help correct power imbalances in the digital economy, such as through user-owned data repositories and broadband networks. Already, some rural electric and telecom cooperatives in the United States have used public and private financing to create successful fiber-to-the-home projects, often in areas that investor-owned providers avoid serving (Talbot, Hessekiel, and Kehl 2017). The European Union has meanwhile adopted policies that aid in financing community-owned renewable power generation (Friends of the Earth Europe 2018) - an initiative inspired, in part, by Louis Kelso's legacy 
(Lowitzsch 2018, 164).

With appropriate policy support, financing could be at least as available for community-owned enterprises as for investor ownership. By drawing on global lessons in targeted sectors such as agriculture and energy, financial mechanisms for community ownership can be generalized across the economymaking them available to help address the accountability crises of the digital economy in particular. It should be at least as attractive for entrepreneurs seeking growth capital or an "exit" (Schneider 2019) to be able to access capital by partnering with their stakeholder communities as through outside investors.

Recommendations in brief:

- Universalize financing mechanisms that have been successful in specific sectors - such as with insurance pools, direct government lending, and appropriate taxation

- Develop digital infrastructure on the basis of ownership by participant communities

- Target incentives toward capital acquisition for communities historically marginalized through under-capitalization

\section{Coordination: from niche to commonwealth}

Cooperativism, like organized labor, is a phenomenon that often refers to itself as a "movement" without always behaving like one. National cooperative associations and the International Co-operative Alliance use the rhetoric of representing a unified community, while in practice the reality is much more fragmented. In the United States, for instance, the operations of the National Cooperative Business Association, which represents all cooperatives, are dwarfed by those of both the rural electric association and the credit union association. This inversion, like so much else, is a product of policy; since US cooperatives depend on industry-specific regulation, they organize and lobby on the basis of industry. In contrast, one might consider a context like Italy, where cooperative legislation is cross-industrial and constitutionally protected (Menzani and Zamagni 2010; Fici 2015). There, a small percentage of a cooperative's profits are expected to be pooled for investing in other cooperatives, and tax benefits encourage retaining "indivisible reserves" that go toward future cooperative development upon a company's liquidation. In Germany, association membership is mandatory for cooperatives (Pentzien 2020). Spanish law formalizes multiple forms of 
"intercooperation" (Sánchez Pachón 2018), and the Basque region's famous Mondragón cooperative is in fact a cluster of tightly integrated but distinct businesses. Thus the international cooperative principle of "cooperation among cooperatives" (International Co-operative Alliance n.d.) can become not merely rhetoric but is enshrined in and encouraged by law.

A broader frame for community ownership could extend beyond just cooperatives to include such entities as ESOPs, nonprofit community land trusts, and equity crowdfunding as part of a bloc working to strengthen alternatives to investor ownership. With a shared policy framework, such entities might then coordinate mutual support and shared policy agendas. And while narrower, industry-specific associations might prefer to take a defensive posture toward emerging innovations, broader associations stand to benefit by helping to seed member businesses in new markets. The Italian cross-industrial federation Legacoop called for a "Cooperative Commons" for digital data in 2012 - several years before talk of cooperative platforms began in earnest elsewhere (Maffettone 2012; Schneider 2018a).

If recent advocacy is a guide, broad community-ownership blocs might seek preferred access to government contracts. Alongside existing preferences for women-owned and minority-owned businesses, worker cooperative proposals in the United States have proposed a preference for worker-owned businesses (Kerr 2015); advocates in the United Kingdom have redirected local pension funds and other public capital investments (Singer 2016). In the digital economy specifically, such preferences might build on efforts to adopt nonproprietary software independent of Silicon Valley tech giants; this has led, for example, to the French government's investment in open-source projects like the Matrix communication protocol and the file-sharing platform NextCloud (Hodgson 2018; Poortvliet 2019). Demands for preferred procurement have extended to non-governmental organizations, such as in efforts to enlist hospitals and universities as "anchor institutions" for local cooperatives (Serang, Thompson, and Howard 2013).

Community-owned enterprises could also serve as their own anchor institutions by leveraging network technology to better coordinate their supply chains. Bauwens and Niaros (2017) have called for digitally enabled "open and contributory value accounting," a paradigm for enabling organizations to make their processes and needs radically transparent, so that other organizations can more readily collaborate. To begin with, open accounting could be contained among community-owned entities to prevent outside exploitation. Such practices may also become obligatory for all; momentum is growing 
behind policy proposals that would require all online platforms to enable greater interoperability with application protocol interfaces (Crémer et al. 2019) or data trusts (McDonald 2019), which third parties could use to build services of their own.

Coordination should spread not just among businesses but also among workers and other kinds of platform users. Consider the 1922 Capper-Volstead Act, which protected US farmer co-op members from becoming targets of antitrust enforcement when wielding legitimate collective power. New Deal labor legislation extended similar protections to unions. Extending this logic to online platforms could empower vulnerable groups to build collective power of their own, from small-business sellers on Amazon to drivers for ride-sharing platforms (Vaheesan and Schneider 2019). While the current resurgence of interest in antitrust policy has focused on dismembering large tech companies (e.g., Hughes 2019), antitrust wields broad powers over coordination rights (Paul 2020). It determines not only when companies abuse their power but also who can organize.

A further form of necessary coordination is cultural policy. Various governments have encouraged alternatives to investor ownership through their powers of information dissemination and narrative building - in contexts ranging from worker cooperatives in Perónist Argentina to the solidarity economy in Quebec. The US Department of Agriculture has long supported conferences, academic centers, publications, and research on cooperatives (Knapp 1973; Anonymous 2019). A strong movement could also hold private institutions accountable. It is an irony that the educational nerve center of investor-powered Silicon Valley, Stanford University, had among its three founding principles "the establishment of cooperative effort in the industrial systems of the future"-by which the founder very explicitly meant community-owned enterprise (Altenberg 1990). Perhaps, if the university had listened, the online economy would already practice community ownership as a matter of course.

Recommendations in brief:

- Encourage cross-industrial associations for community-owned enterprises

- Protect legitimate collective power to counteract corporate power

- Use government resources to study and promote community ownership alongside other forms of business 


\section{Order of operations}

The goals outlined in this chapter are ambitious, significantly more so than what previous generations have achieved. But such ambition is necessary, particularly if the challenge at hand is to equip community-owned enterprise to confront the market power of the investor-owned online platforms, which include some of the most valuable companies in the world. In each vector, I have sought to ground ambition in tangible precedents. By simply generalizing local or industry-specific policies of the past, radical change may be possible through familiar mechanisms - so familiar that by now we might take them for granted.

To conclude, I will consider political strategies for achieving the goals outlined here. In the spirit of the extending past achievements, it is worth reflecting on some of the means by which past policy advances for community ownership have been won. These provide a palette of options for future conditions and opportunities.

Community ownership can be uncommonly cross-partisan. There have been times when it became highly identified with one ideology or another, of course; from the collectivized factories of communist Yugoslavia (Ward 1958) to Tony Benn's advocacy of worker ownership through Britain's Labour government of the 1970s (Tomlinson 1980), the association can stick in the public mind. But minds - and alignments - also tend to change. US Republicans, who once regarded the New Deal's rural electric cooperatives as a type of "creeping communism," turned far friendlier once rural areas served by cooperatives became their electoral base (Doyle 1979; Case 2013). Kenya's powerful agricultural cooperatives began as a segregated institution of British imperialism, then a method for African Socialism, then a tool of capitalist structural adjustment (Wanyama 2008). Italy's apex cooperative associations, founded more than a century ago by Catholics and communists respectively, now seem so indistinct that they are likely to merge (Fici 2015). Louis Kelso courted both Republican and Democratic politicians in his efforts to establish the ESOP (Speiser 1977), and in 2016 expanding employee ownership was on both parties' platforms. Two years later, despite fever-pitch polarization, President Donald Trump signed the Main Street Employee Ownership Act, the most important US legislation on the issue in decades, whose sponsors were nearly down-the-middle bipartisan (Dubb 2018).

Legacy community-ownership institutions represent a further variable. These 
can be quite strong. For instance, the US rural electric and credit union associations wield considerable lobbying power in Washington. But their interests tend to be confined to industry-specific needs, attuned to industryspecific policies. They could even see efforts to build on and expand their own policy successes as a potential threat. Then again, if a new generation of policy proposals improves on legacy arrangements while expanding them to new participants, the legacy institutions could provide decisive political heft. If they hope to see a new generation of success stories in community ownership, these institutions should invest not just in preserving what they have but in enabling what they have yet to envision.

Achieving the New Deal came at the cost of a racist compromises with segregationists, harming the prospects of millions for home-ownership and labor rights for generations. No strategy for community ownership would be worth the name if it accepted such terms. Yet, wherever their loyalties generally lie, advocates of policies to advance community ownership should expect unexpected allies.

\section{References}

Albæk, Svend, and Christian Schultz. 1998. "On the Relative Advantage of Cooperatives." Economics Letters 59 (3): 397-401. https://doi.org/10. 1016/S0165-1765(98)00068-8.

Altenberg, Lee. 1990. "Leland Stanford's Forgotten Vision." Sandstone and Tile 14 (1): 8-20. https://dynamics.org/Altenberg/PAPERS/BCLSFV/.

Anonymous. 2019. "USDA's Division of Cooperative Marketing: An Examination of the Dismantling of the Only Federal Support Program for Cooperatives." https://cooperativecurriculum.org/resources/WhitePaper-on-USDA-Co-op-Program's--decline.pdf.

Antoine, Rose-Marie. 2013. Offshore Financial Law: Trusts and Related Tax Issues. 2 edition. Oxford, United Kingdom: Oxford University Press.

Barlow, John Perry. 1996. "A Declaration of the Independence of Cyberspace." Wired, June 1, 1996. https://www.wired.com/1996/06/ declaration-independence-cyberspace/.

Bauwens, Michel, and Vasilis Niaros. 2017. "Value in the Commons Economy: Developments in Open and Contributory Value Accounting." Heinrich Böll Foundation and the P2P Foundation. http://commonstransition. org/value-commons-economy/. 
Blasi, Joseph, Douglas Kruse, and Richard B. Freeman. 2018. "Broad-Based Employee Stock Ownership and Profit Sharing: History, Evidence, and Policy Implications." Journal of Participation and Employee Ownership 1 (1): 38-60. https://doi.org/10.1108/JPEO-02-2018-0001.

Bogetoft, Peter. 2005. "An Information Economic Rationale for Cooperatives." European Review of Agricultural Economics 32 (February): 191-217. https://doi.org/10.1093/eurrag/jbi010.

Bria, Francesca. 2019. "Barcelona Digital City: Putting Technology at the Service of People." Barcelona: Ajuntament de Barcelona. https://ajuntament.barcelona.cat/digital/sites/default/files/pla_ barcelona_digital_city_in.pdf.

Case, Ted. 2013. Power Plays: The U.S. Presidency, Electric Cooperatives, and the Transformation of Rural America. http://tedcaseauthor.com/ product/power-plays/.

Catalini, Christian, Catherine Fazio, and Fiona Murray. 2016. "Can Equity Crowdfunding Democratize Access to Capital and Investment Opportunities?" MIT Innovation Initiative Lab for Innovation Science and Policy Report. Cambridge, MA: MIT. https://papers.ssrn.com/abstract=2780551.

Chu, Cho-Wen. 2017. "Censorship or Protectionism? Reassessing China's Regulation of Internet Industry." International Journal of Social Science and Humanity 7 (1): 5. http://ijssh.org/vol7/790-MC26.pdf.

Community Shares. 2016. "A Guide to Investing in Community Shares." https://communityshares.org.uk/guide-investing-community-shares.

Corbyn, Jeremy. 2016. "The Digital Democracy Manifesto." https:// d3n8a8pro7vhmx.cloudfront.net/corbynstays/pages/329/attachments/ original/1472552058/Digital_Democracy.pdf?1472552058.

Cracogna, Dante, Antonio Fici, and Hagen Henrÿ. 2013. International Handbook of Cooperative Law. Springer Science \& Business Media.

Crémer, Jacques, Yves-Alexandre de Montjoye, Heike Schweitzer, European Commission, and Directorate-General for Competition. 2019. Competition Policy for the Digital Era. Brussels: European Commission Directorate-General for Competition. http://publications.europa.eu/ publication/manifestation_identifier/PUB_KD0419345ENN.

Curl, John. 2012. For All the People: Uncovering the Hidden History of Cooperation, Cooperative Movements, and Communalism in America. 


\section{PM Press.}

Davidson, John Daniel. 2017. "The Saga of RideAustin." Texas Monthly, June 30, 2017. https://www.texasmonthly.com/the-daily-post/the-sagaof-rideaustin/.

Doyle, Jack. 1979. Lines Across the Land: Rural Electric Cooperatives, the Changing Politics of Energy in Rural America. Washington: The Rural Land \& Energy Project, Environmental Policy Institute.

Dubb, Steve. 2018. "Historic Federal Law Gives Employee-Owned Businesses Access to SBA Loans." Non Profit News | Nonprofit Quarterly. August 14, 2018. https://nonprofitquarterly.org/employee-owned-businesses-sbaloans/.

Fici, Antonio. 2015. "Cooperation Among Cooperatives in Italian and Comparative Law." Journal of Entrepreneurial and Organizational Diversity 4 (2): 64-97. https://doi.org/10.5947/jeod.2015.011.

Florida, Richard. 2017. "Venture Capital Remains Highly Concentrated in Just a Few Cities." CityLab. October 3, 2017. https://www.citylab.com/ life/2017/10/venture-capital-concentration/539775/.

Friends of the Earth Europe. 2018. "Unleashing the Power of Community Renewable Energy." Brussels, Belgium. http://foeeurope.org/unleashingpower-community-energy.

Griffith, Erin. 2019. "More Start-Ups Have an Unfamiliar Message for Venture Capitalists: Get Lost." The New York Times, January 13, 2019. https://www.nytimes.com/2019/01/11/technology/start-ups-rejectingventure-capital.html.

Hodgson, Matthew. 2018. "Matrix and Riot Confirmed as the Basis for France's Secure Instant Messenger App." Matrix.org blog. April 26, 2018. https://matrix.org/blog/2018/04/26/matrix-and-riot-confirmedas-the-basis-for-frances-secure-instant-messenger-app.

Holyoake, George Jacob. 1908. The History of Co-Operation. London: T. F. Unwin. http://archive.org/details/cu31924002593816.

Hueth, Brent. 2014. "Missing Markets and the Cooperative Firm." In Workshop on Producers' Organizations in Agricultural Markets, 22. Toulouse, France.

Hughes, Chris. 2019. "It's Time to Break up Facebook." The New York 
Times, May 9, 2019. https://www.nytimes.com/2019/05/09/opinion/ sunday/chris-hughes-facebook-zuckerberg.html.

International Co-operative Alliance. n.d. "Co-Operative Identity, Values \& Principles." Accessed May 27, 2018. https://ica.coop/en/whats-coop/co-operative-identity-values-principles.

Kelso, Louis O., and Patricia Hetter Kelso. 1986. Democracy and Economic Power: Extending the ESOP Revolution Through Binary Economics. Cambridge, MA: Ballinger Publishing. http://books.google.com?id= _R5XDQAAQBAJ.

Kerr, Camille. 2015. "Local Government Support for Cooperatives." Austin, TX: Austin Cooperative Business Association \& Democracy at Work Institute. https://community-wealth.org/sites/clone.community-wealth. org/files/downloads/paper-kerr.pdf.

Knapp, Joseph G. 1973. The Advance of American Cooperative Enterprise: 1920-1945. Danville, Ill.: Interstate Printers \& Publishers.

Knapp, Joseph G. 1969. The Rise of American Cooperative Enterprise: 1620-1920. Danville, Ill.: Interstate Printers \& Publishers.

Kroncke, Jedidiah J. 2018. "ESOPs and the Limits of Fractionalized Ownership." University of Chicago Legal Forum 2017 (12): 40. https://legal-forum.uchicago.edu/publication/esops-and-limitsfractionalized-ownership.

Lloyd, Jenni, Tom Symons, and Simon Borkin. 2019. "Platform CoOperatives - Solving the Capital Conundrum." Nesta and Co-operatives UK. https://www.nesta.org.uk/report/platform-co-operatives/.

Lowitzsch, Jens. 2018. Energy Transition: Financing Consumer CoOwnership in Renewables. New York, NY: Springer Berlin Heidelberg.

Maffettone, Sebastiano. 2012. "Manifesto." Cooperative Commons. 2012. https://web.archive.org/web/20170313041935/http: //www.cooperativecommons.coop/index.php/en/manifesto.

Mayo, Ed. 2017. A Short History of Co-Operation and Mutuality. Co-operatives UK. https://www.uk.coop/sites/default/files/uploads/ attachments/a-short-history-of-cooperation-and-mutuality_ed-mayoweb_english.pdf.

McDonald, Sean. 2019. "Reclaiming Data Trusts." Centre for International 
Governance Innovation. March 5, 2019. https://www.cigionline.org/ articles/reclaiming-data-trusts.

Menzani, T., and V. Zamagni. 2010. "Cooperative Networks in the Italian Economy." Enterprise and Society 11 (1): 98-127. https://doi.org/10. 1093/es/khp029.

Michael, Christopher. 2017. "The Employee Ownership Trust, an ESOP Alternative." Probate $\&$ Property 31 (1): 42-47.

Mikami, Kazuhiko. 2011. Enterprise Forms and Economic Efficiency: Capitalist, Cooperative and Government Firms. New York: Routledge.

Molk, Peter. 2014. "The Puzzling Lack of Cooperatives." Tulane Law Review 88 (5): 899-958.

Moon, M. Jae. 2017. "Government-Driven Sharing Economy: Lessons from the Sharing City Initiative of the Seoul Metropolitan Government." Journal of Developing Societies 33 (2): 223-43. https://doi.org/10.1177/ $0169796 X 17710076$.

Morell, Mayo Fuster, and Ricard Espelt. 2018. "A Framework to Assess the Sustainability and the Pro-Democratization of Platform Economy." Urban Science 2 (3). https://www.mdpi.com/2413-8851/2/3/61.

Nicholas, Tom. 2019. VC: An American History. Harvard University Press.

Parker, Geoffrey G., Marshall W. Van Alstyne, and Sangeet Paul Choudary. 2016. Platform Revolution: How Networked Markets Are Transforming the Economyand How to Make Them Work for You. W. W. Norton \& Company.

Pasquale, Frank. 2015. The Black Box Society. Cambridge, MA: Harvard University Press.

Paul, Sanjukta. 2020. "Antitrust as Allocator of Coordination Rights." UCLA Law Review 67 (2). https://www.uclalawreview.org/antitrust-asallocator-of-coordination-rights/.

Pentzien, Jonas. 2020. "Political and Legislative Drivers and Obstacles for Platform Cooperativism in the United States, Germany, and France." Working Paper submitted for publication to the Institute for the Cooperative Digital Economy.

Peters, Adele. 2018. "This Company Pioneered a New Business Structure to Preserve Its Mission." Fast Company, July 13, 2018. 
https://www.fastcompany.com/90201663/this-company-pioneered-anew-business-structure-to-preserve-its-mission.

Poortvliet, Jos. 2019. "EU Governments Choose Independence from US Cloud Providers with Nextcloud." Nextcloud blog. August 27, 2019. https://nextcloud.com/blog/eu-governments-choose-independencefrom-us-cloud-providers-with-nextcloud.

Rifkin, Jeremy. 2014. The Zero Marginal Cost Society: The Internet of Things, the Collaborative Commons, and the Eclipse of Capitalism. St. Martin's Publishing Group. http://books.google.com?id= L6afAgAAQBAJ.

Robbins, Robert B., Cindy V. Schlaefer, and Jessica Lutrin. 2018. "From Home Sharing and Ride Sharing to Shareholding." Pillsbury Law. October 25, 2018. https://www.pillsburylaw.com/en/news-and-insights/rule-701revision-uber-airbnb.html.

Rohr, Jonathan, and Aaron Wright. 2017. "Blockchain-Based Token Sales, Initial Coin Offerings, and the Democratization of Public Capital Markets." Cardozo Legal Studies Research Paper 527. https://www.ssrn.com/ abstract $=3048104$.

Sánchez Pachón, Luis Ángel. 2018. "Los acuerdos de intercooperación como mecanismo jurídico de integración de cooperativas." Revesco: Revista de Estudios Cooperativos, no. 126 (January). https://doi.org/10.5209/ REVE.58616.

Schneider, Nathan. 2018a. Everything for Everyone: The Radical Tradition That Is Shaping the Next Economy. New York: Nation Books.

_ 2020a. "Digital Kelsoism: Employee Stock Ownership as a Pattern for the Online Economy." In Reimagining the Governance of Work and Employment, edited by Dionne Pohler, 234-46. Ithaca, NY: Cornell University Press. https://osf.io/7wrab/.

—. 2020b. "User Trusts: Broad-Based Ownership for Online Platforms." Informatik Spektrum, no. 43: 9-14. https://osf.io/puy5d/.

_. 2018b. "An Internet of Ownership: Democratic Design for the Online Economy." The Sociological Review 66 (2): 320-40.

- 2019. "Startups Need a New Option: Exit to Community." Hacker Noon. September 16, 2019. https://hackernoon.com/startups-need-anew-option-exit-to-community-ig12v2z73. 
Scholz, Trebor. 2017. Uberworked and Underpaid: How Workers Are Disrupting the Digital Economy. New York: John Wiley \& Sons. http: //books.google.com?id=0pNNDwAAQBAJ.

_ 2018a. "Andrea Nahles, Head of Social Democratic Party of Germany, Commits to Support Platform Co-Ops." Platform Cooperativism Consortium. August 31, 2018. https://platform.coop/blog/andrea-nahlesdemocratic-party-of-germany/.

. 2018b. "A New Bill of Rights for American Workers Building Support for Cooperatively-Owned Businesses That Are Democratically-Owned and Governed." Platform Cooperativism Consortium. November 30, 2018. https://platform.coop/blog/policy-recommendations-for-unitedstates/.

Scholz, Trebor, and Nathan Schneider. 2016. Ours to Hack and to Own: The Rise of Platform Cooperativism, a New Vision for the Future of Work and a Fairer Internet. New York: OR Books.

Schor, Juliet. 2020. After the Gig: How the Sharing Economy Got Hijacked and How to Win It Back. Berkeley, CA: University of California Press. https://www.ucpress.edu/book/9780520325050/after-the-gig.

Serang, Farzana, J. Phillip Thompson, and Ted Howard. 2013. "The Anchor Mission: Leveraging the Power of Anchor Institutions to Build Community Wealth." College Park, MD: The Democracy Collaborative. https://democracycollaborative.org/content/anchor-mission-leveragingpower-anchor-institutions-build-community-wealth.

Sifry, Micah. 2016. "A Conversation with Trebor Scholz on the Rise of Platform Cooperativism." Civic Hall. October 25, 2016. https://civichall. org/civicist/conversation-with-trebor-scholz-platform-coop/.

Singer, Clifford. 2016. "The Preston Model." The Next System Project. September 9, 2016. https://thenextsystem.org/the-preston-model.

Speiser, Stuart M. 1977. A Piece of the Action: A Plan to Provide Every Family with a \$100,000 Stake in the Economy. New York: Van Nostrand Reinhold Co.

Spicer, André. 2019. "Uber's London Woes Show the Need for a Taxi App Owned by Drivers | André Spicer." The Guardian: Opinion, November 26, 2019. https://www.theguardian.com/commentisfree/2019/nov/26/uberlondon-taxi-app-drivers-cities. 
Spinak, Abby (Abby Elaine). 2014. "Infrastructure and Agency: Rural Electric Cooperatives and the Fight for Economic Democracy in the United States." Thesis, Massachusetts Institute of Technology. http: //dspace.mit.edu/handle/1721.1/87519.

Talbot, David A., Kira Hope Hessekiel, and Danielle Leah Kehl. 2017. "Community-Owned Fiber Networks: Value Leaders in America." Berkman Klein Center for Internet \& Society Research Publication. Harvard University. https://dash.harvard.edu/handle/1/34623859.

Taylor, Keith, and Nathan P. Goodman. 2019. "The StakeholderEmpowering Philanthropy of Edward Filene." Journal of Institutional Economics, October, 1-15. https://doi.org/10.1017/S1744137419000675.

Tomlinson, Jim. 1980. "British Politics and Co-Operatives." Capital $\& 5$ Class 4 (3): 58-65. https://doi.org/10.1177/030981688001200104.

Uniform Law Commission. 2013. "The Uniform Limited Cooperative Association Act (UCLAA): A Summary." Chicago, IL: National Conference of Commissioners on Uniform State Laws. https://www.uniformlaws.org/ HigherLogic/System/DownloadDocumentFile.ashx?DocumentFileKey= 2b40106d-9905-860b-dd4a-847960751b7a\&forceDialog $=0$.

Upside Down Consulting. n.d. "Cooperative Platform Economy Act." Accessed January 3, 2020. https://cooperativeplatform.org/.

Vaheesan, Sandeep, and Nathan Schneider. 2019. "Cooperative Enterprise as an Antimonopoly Strategy." Penn State Law Review 124 (1): 1-55. http://www.pennstatelawreview.org/print-issues/cooperativeenterprise-as-an-antimonopoly-strategy/.

Wanyama, Frederick O. 2008. "The Qualitative and Quantitative Growth of the Cooperative Movement in Kenya." In Cooperating Out of Poverty: The Renaissance of the African Cooperative Movement, edited by Patrick Develtere, Ignace Pollet, and Frederick O Wanyama. Geneva: International Labour Office.

Ward, Benjamin. 1958. "The Firm in Illyria: Market Syndicalism." The American Economic Review 48 (4): 566-89. http://www.jstor.org/stable/ 1808268 .

Wiener, Jason, and Linda Phillips. 2018. "Colorado — 'The Delaware of Cooperative Law'." Fifty by Fifty blog. July 11, 2018. https://medium.com/ fifty-by-fifty/colorado-the-delaware-of-cooperative-law-babedc9e88eb. 
Zuboff, Shoshana. 2019. The Age of Surveillance Capitalism: The Fight for a Human Future at the New Frontier of Power. New York: PublicAffairs. 